\title{
Child Sexual Abuse Among Polish Adult Population: Prevalence and Abuse Characteristics
}

\author{
Milena A. Guziak* \\ * Correspondence concerning this article should be addressed to Milena A. \\ Guaiac, founder and principal researcher of The Lost Childhood Association, \\ contact.lostchildhood@gmail.com
}

\begin{abstract}
The present study aimed to consolidate on and expand on existing knowledge on the issue of child sexual abuse (CSA) by identifying the prevalence of and characteristics of CSA among Polish adult population with inclusion of other gender identities and socio-demographic characteristics. A cross-sectional study was performed, using a self-reporting, anonymous, questionnaire. Data were analyzed by frequency/percentages, using SPSS software. A total of 234 individuals of various gender identity (male, female, non-binary, demigirl, agender, gender fluid) participated in the study $\left(M_{\text {age }}=22.52, S D=6.65\right)$. The results indicate a 39.7\% ( $\mathrm{N}=93)$ prevalence of CSA in the tested Polish population. Of the total sample, $13.2 \%$ knew other 3 or more individuals who suffered from CSA, $14.5 \%$ knew other 2 persons, and $26.1 \%$ knew one individual. Of the abused participants, $36.5 \%$ was of intra- and extrafamilial (51.6\%) nature, whilst $11.8 \%$ experienced both. The mean age the first abuse occurred was 9.20 $(S D=3.43)$. The duration of CSA varied: 2 weeks up to 8 years. The most common type of violation was fondling (91.4\%) and other sexual activities, excluding penetration (62.4\%). All of the CSA victims experienced at least 2 types of sexual violation. The overall prevalence found in the current study was higher than expected, suggesting that victims may currently be more likely to self-report on CSA experiences, as majority of respondents, more than $80 \%$, are in the 18-30 age group. It is suggested that there is a greater need for understating the scale of CSA in Poland and for inclusion of other gender identities in the research on this topic.
\end{abstract}




\section{INTRODUCTION}

Childhood sexual abuse (CSA) is a pervasive problem, affecting children across the globe independently of race, culture, gender, religion, and social strata. A recent systematic review of 55 studies from 24 countries found CSA to range from 8 to $31 \%$ for girls and 3 to 17\% for boys (Barth, Bermetz, Heim, Trelle, and Tonia, 2013). Other worldwide systematic reviews have reported disturbing rates of sexual abuse as well: with averages of $18-20 \%$ for females and of $8-10 \%$ for males. The lowest rates of $11.3 \%$ and $4.1 \%$ for both girls and boys were reported in Asia, whilst the highest, 21.5\% for girls in Australia and 19.3\% for boys in Africa (Pereda, Guilera, Forns, and Gómez-Benito, 2009; Stoltenborgh, Van Ijzendoorn, Euser, and Bakermans-Kranenburg, 2011). Significant gender differences were found in Europe, Asia, United States, and Australia with boys indicating a lower prevalence than with girls. Non-of the above studies included Poland.

\section{Definition of CSA based on the Penal Code of Poland}

The definition of CSA is to some extent stipulated in the Chapter XXV of the Penal Code of Poland, regulating crimes against sexual freedom and decency (Kodeks Karny, 1997 and rev. 2020). The articles of the penal code can be separated into two categories: 1) articles that protect everyone (including minors) against specific sexual behaviours, such as rape (Art. 197), sexual intercourse with abuse dependency relationship (Art. 199) and incest (Art. 201); and 2) articles that specifically protect minors from sexual behaviours or exploitation, such as sexual intercourse with a person below 15 years of age (Art. 200) and involving a minor with pornographic content (Art. 202). The consent age is set at 15 as specified in the penal code and the age of civil majority in Poland is 18 in accordance with the Art. 10 of the Civil Code of Poland (Kodeks Cywilny, 1964 and rev. 2019).

\section{Contact and Non-contact CSA}

Child sexual abuse can be understood as an involvement of "dependent developmentally children or adolescents in sexual activities they do not truly comprehend, and to which they are unable to give full consent (...)" (Schechter \& 
Roberge, 1976). Child sexual abuse consists of contact and non-contact sexual abuse (World Health Organization, 1999). What falls under the umbrella of contact CSA is any activity that involves physical contact with the use of coercion, the threat of force, or force, such as oral, anal, and vaginal penetration with an object or another body part; sexual intercourse; and fondling of private parts. Non-contact CSA, on the other hand, is any act of sexual nature without any physical contact with use of coercion, the threat of force, or force (e.g. exposure to pornographic materials, exhibitionism, voyeurism, and sexual exploitation for financial gain). The involvement of coercion, the threat of force, or force are not always involved in CSA incidents, as some of them might be very subtle and/or unexpected. For example, "incidentally" fondling genitals when dressing up a child, "incidentally" walking on a child when he or she is taking shower, or "incidentally" exposing genitals by walking around in underwear in such a way that a child becomes aware of it. What is important to mention is that CSA results in sexual gratification of the person who perpetrates it.

\section{The Prevalence of CSA in Poland}

In the case of Poland, there is limited research available on the prevalence of CSA. However, some insights on the scale of the violence against children can be found in the data generated by the police, judicial system, NPO organization, and psychiatric and psychological research studies.

In 2017, there were 1,324 reported and confirmed cases of CSA (Art. 200), 626 cases of seduction of a minor below the age of 15 using an ICT system or a telecommunications network (Art. 200a), and 3 cases of incest (Art. 201) (Kodeks Karny, 1997 and rev. 2020a; Komenda Główna Policji, n.d.).

In addition, the Empowering Children Foundation (Fundacja Dajemy Dzieciom Siłę) reported that $6.4 \%$ teenagers experienced contact CSA before the age of 15, whilst $8.9 \%$ non-contact CSA (Włodarczyk and Makaruk; 2013). The study was conducted on the sample of 1005 ( $\mathrm{n}_{\text {boys }}=502$, $\mathrm{n}_{\text {girls }}=503$ ) individuals, age 11-17. A detailed breakdown revealed that more boys (3.9\%) than girls (2.3\%) had a sexual intercourse with an adult. Out of the total sample, $2.4 \%$ declared unwanted touching or being forced to engage in other sexual behaviours. As for non-contact CSA, 5.3\% experienced verbal sexual abuse and 
1.5\% exhibitionism. The latest nationwide report, which was conducted in 2018 on diagnosis of the scale of child abuse on students of $11-17$ of age ( $\mathrm{N}=1115)$, points out that $20 \%$ admitted to have experienced incriminating sexual incidents; and 7\% experienced sexual abuse (Włodarczyk, J., Makaruk, K., Michalski, P., and Sajkowska, M., 2018).

In another study, Heitzman, Lew-Starowicz M., Pacholski, and LewStarowicz Z. (2014) analysed medico-legal reports related to child sexual offenders $(N=257, \mathrm{CSO})$. In relation to characteristics of CSA, the study revealed that the most common type of abuse was fondling (touching genitals, 56.6\%), vaginal intercourse (39\%), oral sex (27.6\%), anal penetration (11.8\%), exhibitionism (25\%), and masturbation of the offender by the victim (14.9\%). Study by Beisert (2011) on the 248 CSOs found similar results: fondling $-65.3 \%$, vaginal intercourse - 39.5\%, oral sex - 26.6\%, anal penetration - 18.1, exhibitionism $-12.9 \%$, and masturbation of the offender by the victim $-15.7 \%$.

In 2016, for the first time in Poland a study on adverse childhood experiences was carried out on the behalf of the World Health Organization and the Ministry of Health on 1772 students $\left(M_{\text {age }}=20.46, S D=1.24\right)$ (Hughes et al., 2019; Makaruk et al., 2018). The main aim of the study was to diagnose the scale of violence experienced in childhood and the possible consequences of these experiences in the form of risky behaviours. In relation to CSA, $4.8 \%$ admitted to have been victims of sexual abuse by an adult.

Another source of information is data generated by the Ministry of Family, Labor and Social Policy (Ministerstwo Rodziny, Pracy i Polityki Społecznej; MPiPS). The 2011's report investigated participants of corrective and educational programs who committed physical and/or psychological and/or sexual violence acts towards a family member/s (MPiPS, 2011). The surveys were distributed by leading specialists invited to cooperate in that study. Out of the sample of 360 participants, $6 \%(n=20)$ used sexual violence towards their family members (intrafamilial abuse), 5\% used sexual violence towards a stepdaughter and 5\% towards a sister. No extrafamilial abuse was reported. Only $2 \%$ and $3 \%$ endured sexual violence in childhood and adulthood, respectively. Three years after that, in 2014, research on diagnosis and comparison of the scale of the phenomenon of domestic violence and assessment of the 
effectiveness of actions taken to prevent domestic violence on behalf of the Ministry of Labour and Social Policy was carried out, which was implemented as part of "Polish Family Free from Violence" campaign (MPiPS, 2014a). What the result showed is that $1.1 \%$ of the sample, out of $2971\left(\mathrm{n}_{\text {female }}=1550, \mathrm{n}_{\text {male }}=\right.$ 1421) respondents, declared that they had experienced sexual violence in the family circle as a child, of which $2.0 \%$ were women and $0.2 \%$ were men. Little more than $4 \%$ of respondents knew families in their surroundings in which sexual violence against children occurred. This was a significantly lower result than that obtained during the study in 2008 , where $4.8 \%$ of respondents knew about sexual violence against children in the immediate environment. Part of this national survey was specific research on diagnosing the phenomenon of violence in the perception of children and adolescents between the age 11 and $17(\mathrm{~N}=$ 1231), including sexual violence towards children (MPiPS, 2014b). The questionnaire assumed that sexual exploitation is manifested by touching the child's intimate parts or forcing the child to touch adults' intimate parts, persuading the child by adults to watch pornographic films or photos, and talking to the child about inappropriate sexual topics. The survey found that in the perception of participants almost all or more than half of their peers experienced at least one type of physical violence; neglect was less frequently mentioned-32\%, psychological violence-23\%, and least often sexual violence- $6 \%$.

Finally, Guziak (2020a, 2020b, 2020c, 2020d, 2020e) investigated the prevalence of CSA, its characteristics, in addition to characteristics of CSA perpetrators by analysing quantitatively a discussion forum. The study found very low prevalence among total forum members. It was reported that the majority of victims were females $(n=80)$ and males $(n=1)$ of age 14-61. Such high rate of female victims was assumed to be due to the nature of the website. The age the abuse occurred ranged from 3-5 (13.6\%), 6-10 (32.1\%), 11-15 (10\%), in $38.3 \%$ cases no information was provided. The most common type of perpetrator was of intrafamilial identity (48.1\%). 


\section{THE CURRENT STUDY}

Fully understanding the scope of CSA problem is with no doubt of great importance. As such, the purpose of this study is to consolidate existing CSArelated knowledge and expand on it by investigating the prevalence and characteristics of CSA in Poland. The study is a part of a larger project, investigating attitudes towards CSA preventive measures, psychological consequences of CSA, and other forms of abuse (physical and psychological). The current study, however, reports in detail on only CSA characteristics among Polish adult population.

First of all, research examining the prevalence of CSA in Poland is limited to traditional gender types (male and female), overlooking other gender identities. As some research suggests the effect of CSA on sexual identity formation among, bisexual, lesbian, gay, and queer (Walker, Hernandez, and Davey, 2012), the study addressed this issue by ensuring inclusion of other gender identities. In the Polish context, to the knowledge of the author, no study so far has considered this factor.

Second of all, much of the literature conducted on members of the general population is devoid of detailed socio-demographic characteristics of victims, in addition to the lack of characteristics of CSA, specifically duration and/or frequency of abuse and the context of abuse (intra and interfamilial context). Literature indicates a victim-perpetrator relationship is associated with the duration of abuse (Faller, (1989). Additionally, suicidal ideation, more depressive symptoms, self-harm, and suicidal ideation seem to be more common for CSA victims abused for longer duration of time, as oppose to individuals abused for shorter duration (Boudewyn and Liem, 1995; Lopez-Castroman et al., 2013; Trickett, Noll, Reiffman, and Putnam, 2001). Considering the above, having knowledge about duration and the context of abuse are important for treatment planning. In relation to socio-demographic information, this study tackled these shortcomings by asking respondents about the highest education obtained, employment, and martial and parental status. In relation to CSA characteristics, questions about duration and context were included in the questionnaire. 


\section{METHOD}

\section{Participants}

The participants of the study consisted of 234 adults recruited through Facebook platform. The age of participants varied between 18 and 65 . The mean age was $22.52(S D=6.65)$. The full characteristics of the sample are shown in Table 1.

Table 1. Participants Characteristics

\begin{tabular}{|c|c|c|c|}
\hline & & $\begin{array}{c}\text { Frequency } \\
(\mathrm{N}=234), \mathrm{n}(\%)\end{array}$ & $\begin{array}{l}\text { Mean Age } \\
(S D)\end{array}$ \\
\hline \multirow[t]{7}{*}{ Gender } & Female & $204(87.2)$ & $22.62(6.88)$ \\
\hline & Male & $17(7.3)$ & $23.00(6.15)$ \\
\hline & Non-binary & $5(2.3)$ & $18.50(1.00)$ \\
\hline & Gender fluid & $2(0.9)$ & $22.00(1.41)$ \\
\hline & Demigirl & $2(0.9)$ & $21.50(3.53)$ \\
\hline & Agender & $1(0.4)$ & \\
\hline & Prefer not to say & $3(1.3)$ & $20.33(2.08)$ \\
\hline \multirow[t]{6}{*}{ Age } & $18-20$ & $111(47.4)$ & $18.92(0.81)$ \\
\hline & $21-30$ & $103(44)$ & $22.88(2.12)$ \\
\hline & $31-40$ & $16(6.8)$ & $36.00(3.08)$ \\
\hline & $41-50$ & $1(0.4)$ & $44(-)$ \\
\hline & $51-60$ & $1(0.4)$ & $59(-)$ \\
\hline & $61-70$ & $2(0.9)$ & $64.00(1.41)$ \\
\hline Employme & Employed & $50(21.4)$ & $24.80(6.01)$ \\
\hline \multirow{9}{*}{ nt Status } & Self-employed & $6(2.6)$ & 30.67 (7.17) \\
\hline & University Student & $121(51.7)$ & $20.41(1.88)$ \\
\hline & Student/Pupil & $13(5.6)$ & $18.42(0.64)$ \\
\hline & Full-time Parent & $8(3.4)$ & $25.00(6.54)$ \\
\hline & Unemployed & $30(12.8)$ & $22.00(5.36)$ \\
\hline & Retired & $2(0.9)$ & $64.00(1.41)$ \\
\hline & Annuity & $2(0.9)$ & $51.50(10.60)$ \\
\hline & Parental Leave & $1(0.4)$ & - \\
\hline & Medical Leave & $1(0.4)$ & - \\
\hline Highest & Doctoral Level & $3(1.3)$ & $46.00(14.73)$ \\
\hline Level of & Master Level & $28(12)$ & 33.34 (10.49) \\
\hline \multirow[t]{8}{*}{ Education } & Bachelor Level & $20(8.6)$ & $24.15(2.62)$ \\
\hline & $\begin{array}{l}\text { Vocational Level (5-year } \\
\text { training) }\end{array}$ & $31(13.2)$ & $20.86(2.31)$ \\
\hline & High School Level & $117(50)$ & $20.29(3.02)$ \\
\hline & Post High-School Level & $25(10.7)$ & $21.40(1.78)$ \\
\hline & Vocational Level (3-year & $1(0.4)$ & - \\
\hline & Training) & & \\
\hline & Primary School Level & $9(3.8)$ & $18.55(1.03)$ \\
\hline & Prefer not to say & $2(0.9)$ & $18.00(0.00)$ \\
\hline Martial & Single & $107(45.7)$ & $20.93(3.68)$ \\
\hline \multirow[t]{2}{*}{ Status } & Relationship (non-married) & $101(43.2)$ & $21.21(3.52)$ \\
\hline & Married & $26(11.1)$ & $34.15(12.10)$ \\
\hline Parental & With Children & $27(11.5)$ & $32.92(12.93)$ \\
\hline Status & Without Children & $207(88.5)$ & $21.14(3.56)$ \\
\hline
\end{tabular}




\section{Materials and Measures}

A questionnaire consisted of socio-demographic questions, questions related to forms of violence (physical, emotional, and sexual violence) and CSA experienced below the age of 15, including the age CSA occurred, the duration of the abuse, context of the abuse (intra- or extrafamilial), types of CSA (contact and noncontact CSA), and awareness about others sexually abused as a child.

\section{Equipment}

IMP SPSS Statistics software, version 25, for MacBook Pro was used to analyse quantitative data obtained from a survey the author created in Google Forms.

\section{Procedure}

A questionnaire with instructions was advertised on Facebook between June 9 and 15, 2020. Using Google Forms, each participant completed demographic questions related to forms of violence experienced: physical, emotional (psychological) and CSA. Those who were abused as children were redirected to questions on consequences the abuse had on them and more details questions on types of CSA experienced. Those who had no such experiences were redirected to a section investigating public opinion on what should be done to prevent CSA in Polish society. The questionnaire was then closed, data transferred to a SPSS spreadsheet, after which deleted from Google Forms.

\section{Data Analysis}

Data was analysed using descriptive statistics such as percentage and frequency.

\section{Ethics}

All participants were fully informed about what they will be asked to do, about the topic of the study and its sensitive nature and potential psychological effect by participating in the study, about what will happen to the data gathered according to GDPR, who and how to contact—should they have any questions, and exclusion and inclusion criteria (Appendix A). In every section of the questionnaire, they were reminded about their right to withdraw from the study and how to proceed in case of any unexpected feelings or reaction. Consent was 
obtained from participants through a Consent Form included in the questionnaire. The participants were asked to complete all sections of the online form, which included confirming that they have read the Participant Information, are aware that their participation is voluntary and they have 2 weeks to withdraw from the study, that they are over eighteen, agree to take part in the study and have read and agreed to how their data will be used and understand what the research team's obligations are to them regarding their data. As the participants have been recruited online they had to tick all the boxes in the Consent Form in order to participate in the study. During the debrief process participants were once again asked to consent to their data being used at the end of the questionnaire. Deception was not used in this study. No request has been in relation to withdrawing their data from the study. Participants were informed that they will not be mentioned by name and their responses will be made anonymous and kept confidential at all times. They were given a unique code at the beginning of the study, which was used if any of participants wish to withdraw. Participants' information has been stored on a password-protected computer. No request has been made so far in relation to withdrawing their data from the study. After the data was transferred to a SPSS sheet, it was removed from Google Forms. The author reports no conflict of interest.

\section{RESULTS}

\section{Prevalence of CSA}

Of the total sample, 39.7\% ( $\mathrm{N}=93)$ had experienced child sexual abuse before the age of 15 . Of the CSA victims, $91.4 \%$ were girls. For boys, the corresponding percentage was 3.2\%. Age group of 18-30 accounted for majority of victims. Full characteristics of CSA victims, by gender, age, education, marital status, parental status, and employment are shown in Table 2.

\section{Awareness about other adults sexually abused as children}

Majority of the participants (53.8\%) know someone who was sexually abuses as a child (Table 3). 
Table 2. Forms of Abuse

\begin{tabular}{|c|c|c|}
\hline & & CSA \\
\hline \multirow[t]{2}{*}{ Total $(\mathrm{N}=234)$} & Yes & $93(39.7)$ \\
\hline & No & $141(60.3)$ \\
\hline \multicolumn{3}{|l|}{ Total Abused $(\mathrm{N}=93)$} \\
\hline \multirow[t]{6}{*}{ Gender } & Female & $85(91.4)$ \\
\hline & Male & $3(3.2)$ \\
\hline & Non-binary & $2(2.15)$ \\
\hline & Gender fluid & $1(1.1)$ \\
\hline & Demigirl & $1(1.1)$ \\
\hline & Prefer not to say & $1(1.1)$ \\
\hline \multirow[t]{6}{*}{ Age } & $18-20$ & $36(38.7)$ \\
\hline & $21-30$ & $45(48.4)$ \\
\hline & $31-40$ & $8(8.6)$ \\
\hline & $41-50$ & $1(1.1)$ \\
\hline & $51-60$ & $1(1.1)$ \\
\hline & $61-70$ & $2(2.15)$ \\
\hline \multirow[t]{10}{*}{ Employment } & Employed & $22(23.7)$ \\
\hline & Self-employed & $4(4.3)$ \\
\hline & University Student & $41(44.1)$ \\
\hline & Student/Pupil & $5(5.4)$ \\
\hline & Full-time Parent & $4(4.3)$ \\
\hline & Unemployed & $12(12.9)$ \\
\hline & Retired & $2(2.15)$ \\
\hline & Annuity & $2(2.15)$ \\
\hline & Parental Leave & $1(1.1)$ \\
\hline & Medical Leave & - \\
\hline \multirow{7}{*}{$\begin{array}{l}\text { The Highest Level of } \\
\text { Education Obtained }\end{array}$} & Doctoral Level & $2(2.15)$ \\
\hline & Master Level & $13(14.0)$ \\
\hline & Bachelor Level & $9(9.7)$ \\
\hline & $\begin{array}{l}\text { Vocational Level (5- } \\
\text { year training) }\end{array}$ & $15(16.1)$ \\
\hline & High School Level & $38(40.9)$ \\
\hline & $\begin{array}{l}\text { Post High-School } \\
\text { Level }\end{array}$ & $9(9.7)$ \\
\hline & Primary School Level & $7(7.5)$ \\
\hline \multirow[t]{3}{*}{ Martial Status } & Single & $37(39.8)$ \\
\hline & $\begin{array}{l}\text { Non-married } \\
\text { Relationship }\end{array}$ & $41(44.1)$ \\
\hline & Married & $15(16.1)$ \\
\hline \multirow[t]{2}{*}{ Parental Status } & With Children & $14(15.0)$ \\
\hline & Without Children & $79(84.9)$ \\
\hline
\end{tabular}

Note $. \mathrm{CSA}=$ Child Sexual Abuse; 
Table 3. Awareness about other adults sexually abused as children

\begin{tabular}{lc}
\hline Awarenss & $\begin{array}{c}\text { Frequency }(\mathrm{N}=234) \\
\mathrm{n}(\%)\end{array}$ \\
\hline I don't know anyone & $108(46.2)$ \\
I know 1 person & $61(26.1)$ \\
I know 2 people & $34(14.5)$ \\
I know 3 or more & $31(13.2)$ \\
\hline
\end{tabular}

\section{Age the Abuse Occurred}

The mean age the abuse occurred was $9.20(S D=3.43)$. The ages of the victims varied between 3 and 15. The most common age the abuse happened was 5 (15.1\%) (Table 4).

Table 4. The Age of the Respondent at the Time of the First CSA

\begin{tabular}{cc}
\hline & Frequency $(\mathrm{N}=$ \\
Age & $\mathrm{n}(\%)$ \\
\hline 3 & $1(1.1)$ \\
4 & $4(4.3)$ \\
5 & $14(15.1)$ \\
6 & $7(7.5)$ \\
7 & $7(7.5)$ \\
8 & $11(11.8)$ \\
9 & $9(9.7)$ \\
10 & $3(3.2)$ \\
11 & $7(7.5)$ \\
12 & $7(7.5)$ \\
13 & $11(11.8)$ \\
14 & $7(7.5)$ \\
15 & $5(5.4)$ \\
\hline
\end{tabular}




\section{Duration of CSA}

The duration of abuse spanned from approx. 2 weeks to up to 8 years and from singular to multiple incidents (Table 5). The longest period of abuse was approx. 8 years $(n=1)$. The duration of abuse for $15.1 \%$ of respondents abused was up to 6 months. For many, it was 1-time (17.2\%) and 2-time incident (12.9\%).

Table 5. Duration/Incidents of CSA

\begin{tabular}{lc}
\hline Duration/Frequency & Frequency $(\mathrm{N}=93)$ \\
& $\mathrm{n}(\%)$ \\
\hline Only 1 time & $16(17.2)$ \\
Only 2 times & $12(12.9)$ \\
Only 3 times & $1(1.1)$ \\
Several times & $2(2.1)$ \\
Approx. 2 weeks & $1(1.1)$ \\
Up to 6 months & $14(15.1)$ \\
6 to 12 months & $8(8.6)$ \\
1 to 2 years & $7(7.5)$ \\
2 to 3 years & $8(8.6)$ \\
3 to 4 years & $1(1.1)$ \\
4 to 5 years & $4(4.3)$ \\
Approx. 8 years & $1(1.1)$ \\
I don't remember & $16(17.2)$ \\
\hline
\end{tabular}

\section{Context of CSA}

According to the data, the most common context of abuse was extrafamilial abuse father $(51.6 \%)$. Of the victims, $11.9 \%(n=11)$ were also exposed to sexual victimization by other intra/extrafamilial individuals (Table 6).

Table 6. Context of CSA

\begin{tabular}{lc}
\hline Context & $\begin{array}{c}\text { Frequency }(\mathrm{N}=93) \\
\mathrm{n}(\%)\end{array}$ \\
\hline $\mathrm{IF}$ & $34(36.5)$ \\
$\mathrm{EF}$ & $48(51.6)$ \\
$\mathrm{IF}+\mathrm{EF}$ & $11(11.8)$ \\
\hline
\end{tabular}

Note. $\mathrm{IF}=$ Intrafamilial Abuse; $\mathrm{EF}=$ Extrafamilial Abuse 


\section{Characterization of CSA}

In general, the practices most commonly described were fondling $(n=85$; 91.4\%), followed by other sexual activities excluding penetration ( $\mathrm{n}=58$; $62,4 \%)$, and forced to touch another person ( $n=41 ; 44.1 \%)$. Other types were less common (Table 7). All victims experienced at least two types of abuse. Every person who reported vaginal penetration through a sexual intercourse $(n=11)$ reported also other types of abuse: fondling $(n=11)$, forced to touch another person ( $\mathrm{n}=5$; Table 8).

Table 7. Characterization of CSA

\begin{tabular}{|c|c|c|}
\hline Type of Abuse & $\begin{array}{c}\text { Frequency }(\mathrm{N}= \\
93) \\
\mathrm{n}(\%)\end{array}$ & CSA Category \\
\hline Sexual intercourse & $11(11.8)$ & Contact \\
\hline Penetration with an object & $9(9.7)$ & Contact \\
\hline $\begin{array}{l}\text { Other sexual activities (not } \\
\text { penetration) }\end{array}$ & $58(62.4)$ & Contact \\
\hline Fondling & $85(91.4)$ & Contact \\
\hline $\begin{array}{l}\text { Forced to watch other having } \\
\text { sex }\end{array}$ & $19(20.4)$ & Non-contact \\
\hline $\begin{array}{l}\text { Forced to watch him } \\
\text { masturbating }\end{array}$ & $28(30.2)$ & Non-contact \\
\hline $\begin{array}{l}\text { Forced to touch another } \\
\text { person }\end{array}$ & $41(44.1)$ & Contact \\
\hline $\begin{array}{l}\text { Asked to share my naked } \\
\text { pictures }\end{array}$ & $22(23.6)$ & Non-contact \\
\hline Other than the above & $33(35.5)$ & 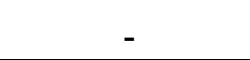 \\
\hline
\end{tabular}

Note . Contact $=$ CSA with physical contact, Non-contact $=$ CSA without physical contact, Other sexual activities (not penetration) $=$ other sexual activities than vaginal penetration (oral sex), Other than above $=$ other sexual activities, including anal penetration, verbal abuse. 
Table 8. Relationship between Types of CSA

\begin{tabular}{|c|c|c|c|c|c|c|c|c|c|}
\hline $\begin{array}{l}\text { Types } \\
\text { of CSA }\end{array}$ & 1 & 2 & 3 & 4 & $\begin{array}{c}5 \\
\mathrm{n} \% \\
\end{array}$ & 6 & 7 & 8 & 9 \\
\hline 1 & 11 & $\begin{array}{c}3 \\
(27.3)\end{array}$ & $\begin{array}{c}7 \\
(63.6)\end{array}$ & $\begin{array}{c}11 \\
(100)\end{array}$ & $\begin{array}{c}1 \\
(9.1)\end{array}$ & $\begin{array}{c}5 \\
(45.4)\end{array}$ & $\begin{array}{c}8 \\
(72.2)\end{array}$ & $\begin{array}{c}5 \\
(45.4)\end{array}$ & $\begin{array}{c}2 \\
(18.2)\end{array}$ \\
\hline 2 & - & 9 & $\begin{array}{c}8 \\
(88.9)\end{array}$ & $\begin{array}{c}8 \\
(88.9)\end{array}$ & $\begin{array}{c}1 \\
(11.1)\end{array}$ & $\begin{array}{c}4 \\
(44.4)\end{array}$ & $\begin{array}{c}5 \\
(55.5)\end{array}$ & $\begin{array}{c}3 \\
(33.3)\end{array}$ & $\begin{array}{c}3 \\
(33.3)\end{array}$ \\
\hline 3 & - & - & 58 & $\begin{array}{c}56 \\
(96.5)\end{array}$ & $\begin{array}{c}13 \\
(22.4)\end{array}$ & $\begin{array}{c}20 \\
(34.5)\end{array}$ & $\begin{array}{c}32 \\
(55.2)\end{array}$ & $\begin{array}{c}16 \\
(27.6)\end{array}$ & $\begin{array}{c}22 \\
(37.9)\end{array}$ \\
\hline 4 & - & - & - & 85 & $\begin{array}{c}16 \\
(18.8)\end{array}$ & $\begin{array}{c}24 \\
(28.2)\end{array}$ & $\begin{array}{c}41 \\
(48.2)\end{array}$ & $\begin{array}{c}21 \\
(24.7)\end{array}$ & $\begin{array}{c}27 \\
(31.8)\end{array}$ \\
\hline 5 & - & - & - & - & 19 & $\begin{array}{c}6 \\
(31.6)\end{array}$ & $\begin{array}{c}10 \\
(52.6)\end{array}$ & $\begin{array}{c}9 \\
(47.4)\end{array}$ & $\begin{array}{c}5 \\
(26.3)\end{array}$ \\
\hline 6 & - & - & - & - & - & 28 & $\begin{array}{c}20 \\
(71.4)\end{array}$ & $\begin{array}{c}11 \\
(39.3)\end{array}$ & $\begin{array}{c}11 \\
(39.3)\end{array}$ \\
\hline 7 & - & - & - & - & - & - & 41 & $\begin{array}{c}16 \\
(39.0)\end{array}$ & $\begin{array}{c}14 \\
(34.1)\end{array}$ \\
\hline 8 & - & - & - & - & - & - & - & 22 & $\begin{array}{c}8 \\
(36.4)\end{array}$ \\
\hline 9 & - & - & - & - & - & - & - & - & 33 \\
\hline
\end{tabular}

Note. 1 = Sexual intercourse, $2=$ Penetration with an object, $3=$ Other sexual activities, (not penetration), $4=$ Fondling, $5=$ Forced to watch other having sex, 6 $=$ Forced to watch him masturbating, $7=$ Forced to touch another person, $8=$ Asked to share my naked pictures, $9=$ Other than above. Shaded fields indicate the total cases of a given CSA type.

\section{DISCUSSION}

This article further contributes to the literature regarding prevalence and characteristics of CSA in Poland. The present study had three main objectives: a) to investigate the prevalence of CSA among Polish adult population adolescents, b) to determine detail characteristics of CSA, and c) to determine detail characteristics of CSA victims.

It was found that the prevalence of CSA (before 15 years of age) among 243 Polish adults examined was 39.7\%. Females were more likely to be victims of CSA than males and other genders. The findings are similar to the previously reported ones in Poland; however, it is important to consider the number of male respondents was rather low compare to female respondents and other gender identities. Although it is understood that the higher prevalence amongst girls is 
expected (Barth et al., 2013), there is some evidence suggesting that it may be subject to change depending on the type of abuse experienced. For example, the overall higher prevalence was reported for girls than for boys in one study in Poland; however, more boys than girls experienced 'sexual contact' before the age of 15 with a person of 18 years of age or older under mutual consent (Włodarczyk and Makaruk, 2013). Although from the perspective of the penal code, this is considered as a punishable act (Kodeks Karny, 1997 and rev. 2020a), one study, investigating the age of sexual initiation of Polish adolescents $(N=$ 1753), found that teenaged boys $(n=118)$ and girls $(n=79)$ had their first sexual intercourse before and at the age 15 (Izdebski and Wąż, 2018). The study did not report on the nature of the sexual initiation for girls and boys. In addition, of the self-reported CSA experiences, 51.6\% occurred in an extrafamilial context: by a person who victims do not consider as a family member; $36.5 \%$ in intrafamilial context (a person considered as a family member), remaining cases were of both nature. These results cannot be confirmed by other research; however, one study that investigated characteristics of CSA perpetrators found the most common type of a perpetrator identity $(\mathrm{N}=81,34.8 \%$ unidentified perpetrator $)$ to be a family member for $48.1 \%$ CSA victims, including a biological father (16\%), a sibling (9.9\%), a stepfather, an uncle (3.0\%), a cousin (7.4), another relative $(8.6 \%)$, and grandfather (4.9\%). Some of the victims of intrafamilial context were victimised by several family members (Guziak, 2020e). Furthermore, of the total sample of the present study, $13.2 \%$ knew other 3 or more individuals who suffered from CSA, $14.5 \%$ knew other 2 persons, and $26.1 \%$ knew one individual. The knowledge of members of the general population about abused adults as children or abused children heightens the overall prevalence rate. The overall prevalence found is higher than expected, suggesting that victims may currently be more likely to self-report on CSA experiences, as majority of victims, more than $80 \%$, are in the $18-30$ age group. The number of respondents in older age groups was very low. It is suspected that this may be due to traditional way of thinking about sexual affairs.

The present study found that of the abused respondents $(\mathrm{N}=93)$, the most reported type of abuse was fondling (91.4\%) followed by other types of sexual activities excluding penetration (62.4\%) and forced to touch the abuser 
(44.1\%). Sexual intercourse accounted for only $11.8 \%$. The result is similar to the results in studies by Heitzman et al. (2014) and Beisert (2011), showing that the most common type of CSA found was fondling (56.6\%) and 65.3\%, respectively. Among individuals abused there was no person who experienced only one type of abuse.

The findings show that all individuals abused were sexually abused when they were under the age of consent. Research into the prevalence of CSA indicates that sexual abuse in many different forms is seen to occur in all ages (World Health Organization, 2002). Investigating the age at the onset of abuse is important as it may ensure a better treatment planning and treatment success. Research shows that sexual abuse during childhood and adolescence target specific regions of brain, (i.e. visual, somatosensory, and auditory cortex) and pathways that are responsible for processing and conveying the aversive experiences, which may disrupt especially in children cognitive, language, and social development (Teicher and Samson, 2016).

\section{Limitations and Future Research}

Several shortcomings of this study must be noted. First, measurements of research variables were based on self-reporting from respondents and validity could not be tested. However, compare to the previous study (Guziak, 2020a; 2020b; 2020c; 2020d; 2020e) the profiles of victims and CSA characteristic is much more informative and complete. Another strengths of the study is that it was inclusive of other gender identities - to the knowledge of the author no previous studies reported on such a detailed gender distinction. In relation to the prevalence of CSA, it was difficult to compare it with prevalence rates reported elsewhere on CSA-type level primarily to due differing definitions of types of CSA and differences in the populations surveyed. Yet another strength of the study is that it addresses limitations of previous research by examining in depth sociodemographic characteristics of victims and characteristics of CSA; consolidate the existing and expands on it. The fact that only few participants were of male and queer identities as well as of older generation suggests that a more sampling technique, aiming at these groups, should be reconsidered. Future research should mitigate these shortcomings. 
As being part of the larger research project, future research will examine differences between intra and extrafamilial CSA characteristics, the psychological impact of CSA on victims, and attitudes towards preventive measure for CSA.

\section{Conclusions}

The results of the present study emphasize the importance of

a) reporting various gender identities when measuring the rates of CSA prevalence and

b) considering types of abuse and gender differences when measuring the prevalence of CSA.

The study also indicates willingness of younger generations to self-disclose CSA and that CSA is an issue across various socio-demographic characteristics. 


\section{Reference}

Barth, J., Bermetz, L., Heim, E., Trelle, S., \& Tonia, T. (2013). The current prevalence of child sexual abuse worldwide: A systematic review and metaanalysis. International Journal of Public Health, 58(3), 469-483. https://doi.org/10.1007/s00038-012-0426-1

Beisert, M. (2011) Pedofilia. Geneza i mechanizm zaburzenia. Gdańsk: Gdańskie Wydawnictwo Psychologiczne

Boudewyn, A. C., \& Liem, J. H. (1995). Childhood sexual abuse as a precursor to depression and self-destructive behavior in adulthood. Journal of traumatic stress, 8(3), 445-459. https://doi.org/10.1007/BF02102969

Dube, S. R., Williamson, D. F., Thompson, T., Felitti, V. J., \& Anda, R. F. (2004). Assessing the reliability of retrospective reports of adverse childhood experiences among adult HMO members attending a primary care clinic. Child Abuse \& Neglect, 28, 729-737. https://doi.org/10.1016/j.chiabu.2003.08.009

Faller, K., C. (1989). The role relationship between victim and perpetrator as a predictor of characteristics of intrafamilial sexual abuse. Child and Adolescent Social Work Journal, 6, 217-229. http://dx.doi.org/10.1007/BF00755849

Guziak, A., M. (2020a). Występowanie Przemocy Seksualnej wobec Dzieci w Polsce: Ilościowa Analiza Internetowego Forum Dyskusyjnego dla Kobiet. The Lost Childhood Association. https://doi.org/10.13140/RG.2.2.13977.24166

Guziak, A., M. (2020b). Investigating the Prevalence of Child Sexual Abuse in Poland: A Quantitative Analysis of an Online Female Discussion Forum. The Lost Childhood Association. https://doi.org/10.13140/RG.2.2.12329.01125

Guziak, A., M. (2020c). Characteristics of Child Sexual Abuse in Poland: A Quantitative Retrospective Analysis of an Online Female Discussion Forum. The Lost Childhood Association. https://doi.org/10.13140/RG.2.2.32499.76321

Guziak, A., M. (2020d). Charakterystyka Zjawiska Wykorzystywania Seksualnego Dzieci w Polsce: Ilościowa Analiza Internetowego Forum Dyskusyjnego dla Kobiet. The Lost Childhood Association. https://doi.org/ 10.13140/RG.2.2.30320.69120

Guziak, A., M. (2020e). Perpetrators of Child Sexual Abuse in Poland: A Quantitative Analysis of an Online Female Discussion Forum. The Lost Childhood Association. Manuscript in preparation. 
Heitzman, J., Lew-Starowicz, M., Pacholski, M., \& Lew-Starowicz, Z. (2014).

Wykorzystywanie seksualne dzieci w Polsce - analiza badań 257

sprawców, którzy popełnili przestępstwa seksualne wobec

małoletnich. Psychiatria polska, 48(1), 105-120.

Izdebski, Z., \& Wąż, K. (2018). Aktywność seksualna młodzieży 15-letniej. In Mazur, J., \& Małkowskiej-Szkutnik, A. (Eds) Zdrowie uczniów w 2018 roku na tle nowego modelu badań HBCS (pp. 143-146). Istytut Matki I Dziecka.

Kodeks Cywilny, Rozdział XXV, Art. 10, (1964 \& rev. 2019).

http://prawo.sejm.gov.pl/isap.nsf/download.xsp/WDU19640160093/0/D 19640093.pdf

Kodeks Karny, Rozdział XXV, Art. 197-205, (1997 \& rev. 2020). http://prawo.sejm.gov.pl/isap.nsf/download.xsp/WDU19970880553/U/D 19970553Lj.pdf

Komenda Główna Policji (2020). Przemoc w rodzinie. Retrieved July, 242020 from https://statystyka.policja.pl/st/wybrane-statystyki/przemoc-wrodzinie/50863,Przemoc-w-rodzinie.html

Komenda Główna Policji. (n.d.). Przestępstwa przeciwko wolności seksualnej i obyczajności (197-205). Retrieved April 15, 2020 from http://www.statystyka.policja.pl/st/kodeks-karny/przestepstwaprzeciwko-6

Lopez-Castroman, J., Melhem, N., Birmaher, B., Greenhill, L., Kolko, D., Stanley, B., Zelazny, J., Brodsky, B., Garcia-Nieto, R., Burke, A. K., Mann, J. J., Brent, D. A., \& Oquendo, M. A. (2013). Early childhood sexual abuse increases suicidal intent. World psychiatry : official journal of the World Psychiatric Association (WPA), 12(2), 149-154. https://doi.org/10.1002/wps.20039

Makaruk, K, Włodarczyk, J., Sethi, D., Michalski, P., Szredzińska, R., and Karwowska, P. (2018). Survey of adverse childhood experiences and associated health-harming behaviours among polish students. World Health Organization.

http://www.euro.who.int/_data/assets/pdf_file/0016/361303/acereport-poland-en.pdf?ua=1

Ministerstwo Rodziny, Pracy i Polityki Społecznej. (2011). Diagnoza dotycząca osób stosujących przemoc w rodzinie: badanie uczestników programów oddziaływań korekcyjno-edukacyjnych.

https://archiwum.mpips.gov.pl/gfx/mpips/userfiles/_public/1_NOWA\%2 0STRONA/Przemoc\%20w\%20rodzinie/dane\%20statystyczne/5\%20RAPO RT_PRZEMOC_W_RODZINIE_SPRAWCY_OGOLNOPOLSKIE_FIN.pdf 
Ministerstwo Rodziny, Pracy i Polityki Społecznej. (2014a). Badania porównawcze oraz diagnoza skali występowania przemocy $\mathrm{w}$ rodzinie wśród osób dorosłych i dzieci, z podziałem na poszczególne formy przemocy wraz z opisem charakterystyki ofiar przemocy i sprawców. https://archiwum.mpips.gov.pl/gfx/mpips/userfiles/_public/1_NOWA\%2 0STRONA/Pomoc\%20spoleczna/przemoc\%20w\%20rodzinie/RC1-3.pdf

Ministerstwo Rodziny, Pracy i Polityki Społecznej. (2014b). Diagnoza zjawiska przemocy i możliwości uzyskania pomocy w sytuacji doświadczania przemocy w percepcji dzieci i młodzieży. https://archiwum.mpips.gov.pl/gfx/mpips/userfiles/_public/1_NOWA\%2 OSTRONA/Pomoc\%20spoleczna/przemoc\%20w\%20rodzinie/RC2.pdf

Pereda, N., Guilera, G., Forns, M., \& Gómez-Benito, J. (2009). The prevalence of child sexual abuse in community and student samples: A metaanalysis. Clinical Psychology Review, 29(4), 328-338. https://doi.org/10.1016/j.cpr.2009.02.007

Schechter, M.D. \& Roberge, L. (1976). "Sexual exploitation”. In R. Helfer \& C.H. Kempe (Eds.), Child abuse and neglect: The family in the community. Ballinger.

Stoltenborgh, M., Van Ijzendoorn, M., Euser, E., \& Bakermans-Kranenburg, M. (2011). A Global Perspective on Child Sexual Abuse: Meta-Analysis of Prevalence Around the World. Child Maltreatment, 16(2), 79-101. https://doi.org/10.1177/1077559511403920

Teicher, M. H., \& Samson, J. A. (2016). Annual Research Review: Enduring neurobiological effects of childhood abuse and neglect. Journal of child psychology and psychiatry, and allied disciplines, 57(3), 241-266. https://doi.org/10.1111/jcpp.12507

Trickett, P. K., Noll, J. G., Reiffman, A., \& Putnam, F. W. (2001). Variants of intrafamilial sexual abuse experience: implications for short- and long-term development. Development and psychopathology, 13(4), 1001-1019. https://doi.org/10.1017/S0954579401004138

Walker, M. D., Hernandez, A., M., \& Davey, M. (2012). Childhood Sexual Abuse and Adult Sexual Identity Formation: Intersection of Gender, Race, and Sexual Orientation. The American Journal of Family Therapy, 40(5), 385-398. https://doi.org/10.1080/01926187.2011.627318

Włodarczyk, J., \& Makaruk, K. (2013). Ogólnopolska diagnoza problemu przemocy wobec dzieci. Fundacja Dajemy Dzieciom Siłę. [PDF] https://fdds.pl/wp- 
content/uploads/2016/05/Ogolnopolska_diagnoza_problemu_przemocy_ wobec_dzieci_Wyniki_badania_2013.pdf

Włodarczyk, J., Makaruk, K., Michalski, P., and Sajkowska, M. (2018).

Ogólnopolska diagnoza skali i uwarunkowań krzywdzenia dzieci. Fundacja Dajemy Dzieciom Siłę. https://fdds.pl/wpcontent/uploads/2018/12/Og\%C3\%B3lnopolska-diagnoza-skali-iuwarunkowa\%C5\%84-krzywdzenia-dzieci_Wyniki-badania_2018.pdf

World Health Organization (1999). Report of the consultation on child abuse prevention (WHO/HSC/PVI/99.1). http://www.who.int/mip2001/files/2017/childabuse.pdf

World Health Organization. (2002).World report on violence and health. http://whqlibdoc.who.int/hq/2002/9241545615.pdf 
